\title{
TELAAH ATAS EFEKTIVITAS PEMBELAJARAN BILINGUAL DI SEKOLAH TINGGI ILMU PELAYARAN
}

\author{
Tristanti ${ }^{1}$ \\ ${ }^{1}$ Prodi Ketatalaksanaan Angkutan Laut dan Kepelabuhanan \\ Sekolah Tinggi Ilmu Pelayaran, Jakarta \\ Jl. Marunda Makmur No. 1 Cilincing, Jakarta Utara. Jakarta 14150
}

Abstrak

Lembaga Pendidikan Pelayaran perlu dukungan dan dorongan untuk pengembangan program bilingual bagi taruna ataupun pelaut pada umumnya di masa yang akan datang. Selama ini Bahasa Inggris yang merupakan bahasa asing di Indonesia masih dianggap sebagai sebuah hambatan bagi komunikasi pelaut di atas kapal, terutama di atas kapal-kapal milik perusahaan asing. Desain penelitian yang digunakan dalam studi ini termasuk metode campuran: survei kuantitatif yang dilakukan pada taruna Nautika semester akhir, pengamatan Lapangan dan wawancara pada dosen dan taruna. Penelitian ini bertujuan untuk menggali persepsi taruna dan dosen tentang pembelajaran dalam Bahasa Inggris dalam kaitannya dengan topik pengajaran bilingual atau bilingual dalam kelas. Sebagian mata kuliah di Prodi Nautika sudah diajarkan dalam Bahasa Inggris dan bahasa Indonesia atau secara bilingual. Sebagian pengajar memiliki kemampuan mengajar dengan bilingual dan mampu mengembangkan metode penyampaian yang baik sehingga target pemahaman substansi materi pembelajaran dapat terpenuhi.

Copyright ( 1 2020, Prosiding Seminar Pelayaran dan Riset Terapan

Kata Kunci : Bilingual, Bahasa Asing, Metode Pembelajaran, Pendidikan Pelayaran

Permalink/ DOI : https://doi.org/10.36101/pcsa.v2i1.124

\section{PENDAHULAN}

Peserta didik pada lembaga pendidikan pelayaran disiapkan untuk masuk dalam pasar kerja yang berdaya saing tinggi dan bersifat global. Lulusan lembaga pendidikan ini akan bersaing dengan SDM pelaut dan pelaku industri pelayaran dari berbagai negara. Dan pada saat sudah diterima bekerja pada industri maritim, tak jarang pula mereka akan bersinggungan dengan bahasa dan budaya bangsa-bangsa asing lainnya dari berbagai negara.

Bahasa Inggris yang sampai saat ini menjadi 'lingua franca' bagi dunia pelayaran yang semakin terbuka dan 'borderless'. Oleh karena itulah penguasaan bahasa Inggris menjadi salah satu kunci pembuka peluang kerja pada era ini, sehingga mengajarkan Bahasa Inggris menjadi sebuah tuntutan tersendiri. Belajar bahasa asing (Bahasa Inggris) tentunya membutuhkan praktik, learning by doing. Pembiasaan dalam penggunaannya akan mendorong kepercayaan diri untuk menggunakan bahasa asing sebagai bahasa kedua selain Bahasa Ibu dan Bahasa Indonesia. Di negara kita, Bahasa Inggris ditempatkan sebagai bahasa asing utama yang diajarkan di berbagai sekolah menengah dan universitas di Indonesia berdasarkan Keputusan Menteri Pendidikan No. 060/U/1993 tertanggal 25 Februari 1993. Sampai saat ini sebenarnya telah banyak terjadi perkembangan dalam kurikulum dan metode pembelajaran dalam pengajaran bahasa Inggris, namun pada kenyataannya, sangat sulit untuk pembelajar di Indonesia menggunakan bahasa Inggris walaupun dalam percakapan sederhana.

Kesulitan dalam penyampaian substansi materi menggunakan Bahasa Inggris akan bisa ditanggulangi manakala pengajar mampu mengembangkan metode pengajaran yang menarik. Mengingat salah satu 'kelemahan' lulusan sekolah pelaut di Indonesia sampai saat ini adalah dalam hal kemampuan 
menggunakan Bahasa Inggris dalam komunikasi.

Diharapkan penelitian ini akan menggugah kesadaran dan komitmen untuk mengembangkan strategi dalam pengajaran bilingual. Dengan demikian keluaran atau lulusan lembaga pendidikan pelayaran di Indonesia akan semakin kompetitif, mampu bersaing dengan pelaut-pelaut dari negara lain.

Adapun tujuan dalam penelitian ini yaitu:

1. Untuk menggali persepsi taruna dan dosen tentang pembelajaran dalam Bahasa Inggris dalam kaitannya dengan topik pengajaran bilingual atau bilingual dalam kelas.

\section{METODE PENELITIAN}

Jenis penelitian yang digunakan adalah deskriptif kuantitatif. Penelitian dilakukan pada taruna Nautika semester akhir Sekolah Tinggi Ilmu Pelayaran Jakarta. Analisis data yang digunakan adalah deskriptif kualitatif. Teknik pengumpulan data dilakukan dengan observasi, dokumentasi dan studi pustaka.

\section{HASIL DAN PEMBAHASAN}

Bahasa Inggris di Indonesia secara umum diajarkan sebagai bahasa asing. Istilah 'bahasa asing' dalam bidang pengajaran bahasa berbeda dengan 'bahasa kedua'. Bilamana dianggap sebagai bahasa asing maka bahasa tersebut tidak digunakan sebagai alat komunikasi di negara tertentu di mana bahasa tersebut diajarkan, misalnya Bahasa Inggris di Indonesia. Ia diajarkan disekolah namun tidak dijadikan sebagai bahasa untuk berkomunikasi secara umum di masyarakat. Sedangkan bagi bahasa kedua, ia menjadi bahasa yang bukan bahasa utama namun menjadi salah satu bahasa yang digunakan secara umum di suatu negara, contohnya bahasa Inggris di Malaysia yang dipakai sebagai bahasa kedua. Media massa, komunikasi, dan pembicaraan di negara tersebut kerap menggunakan bahasa Inggris.
Sementara Bahasa asing biasanya diajarkan sebagai salah satu mata pelajaran di sekolah dengan tujuan berkomunikasi dasar serta menguasai 4(empat) ketrampilan berbahasa (menyimak, membaca, menulis, berbicara) dalam bahasa tersebut dalam batasan tertentu.

Pembelajaran diupayakan untuk mampu mengkondisikan lingkungan belajar sehingga mendukung terjadinya perubahan yang terjadi pada siswa. sebab itu sekolah harus membekali siswanya dengan kemampuan dan keterampilan yang stategis (Arini, 2013). Salah satu kemampuan dan ketrampilan itu adalah berbahasa atau berkomunikasi.

Arnyana (2008) menyebutkan bahwa dalam proses pembelajaran bilingual salah satu faktor yang sangat menentukan keterlaksanaan model ini adalah pengajar. Dalam proses pembelajaran bilingual, setiap pengajar dituntut untuk memiliki penguasaan yang baik terhadap materi pelajaran dan kemampuan komunikasi dalam bahasa Inggris, selain itu disebutkan juga untuk dapat menerapkan model pembelajaran ini diperlukan siswa yang memiliki dasar dalam kemampuan berkomunikasi dengan bahasa Inggris.

Pendidikan bilingual adalah istilah yang merujuk pada pengajaran konten akademik dalam dua bahasa, dalam hal ini bahasa Indonesia dan Bahasa Inggris. Bagaimana cara kerja pendidikan bilingual? Ada berbagai model program yang dapat digunakan dalam pendidikan bilingual. Secara historis, model program yang digunakan untuk Pembelajar Bahasa Inggris (ELL) telah berfokus pada membantu transisi siswa dari bahasa asli mereka ke bahasa Inggris.

Menurut Arnyana (2008), tujuan yang ingin dicapai dengan pembelajaran bilingual adalah (1) meningkatkan penguasaan materi pelajaran, (2) meningkatkan kemampuan berbahasa Inggris dalam forum ilmiah maupun non-ilmiah, (3) mampu mengakses pengetahuan ilmiah dari berbagai media 
internasional, serta (4) mampu berkomunikasi antar siswa baik dari dalam maupun luar negeri.

Sedangkan menurut Chodijah (2000), manfaat ganda dari penggunaan bahasa asing bagi siswa adalah siswa dapat belajar bahasa dan sekaligus konten pelajaran dimana masing-masing pengajar menunjukkan keseriusan dalam mengampu proses pembelajaran dengan menggunakan bahasa Inggris sebanyak yang mereka bisa. Hal ini ditunjukkan oleh frekuensi penggunaan bahasa Inggris yang berbeda.

Sedangkan di sisi yang lainnya kita menemukan pengajar yang melaksanakan pembelajaran dengan bahasa Inggris menyadari bahwa walaupun mereka menggunakan bahasa Inggris saat mengajar, sesungguhnya mereka belum percaya diri dengan apa yang mereka sampaikan dalam Bahasa Inggris. Namun demikian, pengajar merasa yakin bahwa keberanian ini berdampak terhadap motivasi siswanya untuk mengembangkan kemampuan menggunakan bahasa asing tersebut. Penggunaan bahasa Inggris sebagai pengantar pembelajaran nantinya akan berhasil mengembangkan pembelajaran dan sekaligus penguatan bahasa bagi siswa. Namun hal yang perlu diperhatikan juga adalah kesiapan sekolah untuk menerapkannya (Muslich, 2010).

Sampai dengan saat ini, taruna STIP menerima pengajaran bahasa Inggris dalam kegiatan ekstrakurikuler setelah mereka kuliah, setidaknya 2 (dua) kali dalam seminggu. Selain itu terdapat pula beberapa program lainnya yang ditujukan untuk penguatan kemampuan mereka berpidato dalam Bahasa Inggris di depan umum, yaitu melalui kegiatan English Speech di Lapangan Bintang pada pagi hari. Berbagai kegiatan tersebut bertujuan untuk menyiapkan taruna agar memiliki kemampuan, keberanian dan kepercayaan diri dalam berbicara baik di lingkup terbatas maupun di depan umum dengan menggunakan Bahasa Inggris. Lantas bagaimana dengan penyiapan tenaga pengajar/dosen dalam penggunaan Bahasa Inggris di kampus? Kampus perlu mempertimbangkan mengenai dosen-dosen yang sudah berkompeten dalam menggunakan bahasa Inggris. Karena apabila tidak memperhatikan hal demikian maka tujuan dari penggunaan bahasa Inggris sebagai pengantar pembelajaran akan sulit terlaksana. STIP diharapkan mampu memberikan pelatihan Bahasa Inggris kepada para dosen agar nantinya dapat memberikan perkuliahan secara optimal dengan menggunakan pengantar bahasa Inggris di kelas.

Sugianto (2014), mendefinisikan kelas bilingual adalah pembelajaran yang materi pelajaran, proses belajar mengajar, dan penilaiannya disampaikan dalam bahasa Indonesia dan bahasa Inggris. Dalam arti lain kelas bilingual merupakan pembelajaran yang dalam proses belajar mengajar dan penilaianya menggunakan dua sistem bahasa yaitu bahasa Indonesia dan bahasa Inggris. Sedangkan menurut Chodijah (2000), kelas bilingual merupakan kelas yang dapat membangun komunitas berbahasa Inggris secara natural di lingkungan kelas maupun sekolah. Proses belajar mengajar dengan dua pengantar yaitu Bahasa Indonesia dan Bahasa Inggris dapat berjalan efektif dan efisien sampai tujuan yang telah ditetapkan dapat tercapai dan mampu meningkatkan mutu pembelajaran.

\subsection{Penyajian Data}

Pada Responden ditanyakan beberapa pertanyaan yang dirangkum hasilnya sebagai berikut.

Tabel 1. Rangkuman Hasil Pertanyaan Responden

\begin{tabular}{|c|l|c|c|c|c|c|}
\hline NO & \multicolumn{1}{|c|}{ PERTANYAAN } & STS & TS & S & SS & N \\
\hline 1 & $\begin{array}{l}\text { Pengajar sebaiknya } \\
\text { menggunakan metoda } \\
\text { bilingual }\end{array}$ & 2 & 2 & 18 & 25 & 47 \\
\hline 2 & $\begin{array}{l}\text { Pengajar telah } \\
\text { menggunakan bilingual }\end{array}$ & 2 & 12 & 32 & 9 & 55 \\
\hline 3 & $\begin{array}{l}\text { Pengajar - bilingual- baik } \\
\text { dan jelas }\end{array}$ & 0 & 14 & 30 & 10 & 54 \\
\hline 4 & $\begin{array}{l}\text { Pengajar - bahan } \\
\text { presentasi bhs inggris }\end{array}$ & 0 & 20 & 31 & 6 & 57 \\
\hline
\end{tabular}




\begin{tabular}{|c|l|c|c|c|c|c|}
\hline 5 & Taruna memahami & 0 & 7 & 27 & 8 & 42 \\
\hline 6 & $\begin{array}{l}\text { Tersedia bahan ajar - } \\
\text { bilingual }\end{array}$ & 2 & 11 & 36 & 7 & 56 \\
\hline 7 & $\begin{array}{l}\text { Bilingual - motivasi } \\
\text { berbahasa inggris }\end{array}$ & 1 & 4 & 30 & 20 & 55 \\
\hline 8 & $\begin{array}{l}\text { bilingual - meningkatkan } \\
\text { kemampuan }\end{array}$ & 1 & 1 & 27 & 26 & 55 \\
\hline 9 & $\begin{array}{l}\text { Taruna senang berbahasa } \\
\text { inggris }\end{array}$ & 5 & 3 & 26 & 20 & 54 \\
\hline & Akumulasi Jawaban & 13 & 74 & 257 & 131 & \\
\hline
\end{tabular}

Sebagian besar dosen mata kuliah wajib saat ini sebenarnya sudah dimungkinkan menggunakan beberapa media pembelajaran/peraga, seperti demonstrasi, pemodelan, video, penggunaan realia dan visual. Pengembangan kosakata sangat penting dalam sebagian besar mata kuliah, dan keterampilan mendengarkan dikembangkan lebih dari keterampilan berbicara.

Dukungan klarifikasi dan perancah disediakan ketika diperlukan, dan teknologi, seperti TV dan laptop, hadir di sebagian besar ruang kelas dan digunakan walau tak sering. Namun sayangnya, tidak sering ditemui dosen yang melihat pratinjau atau mengaktifkan pengetahuan yang telah diajarkan sebelum mengajarkan pelajaran utama, penggunaan pertanyaan dan kegiatan berpikir yang lebih tinggi/kritis, pengajaran terpusat pada taruna, pekerjaan kelompok atau pasangan, atau handson kegiatan interaktif. Kebanyakan pelajaran /kuliah masih terfokus pada mendengarkan, membaca, dan menulis daripada berbicara. Sementara untuk pertanyaan esai tentang apakah saran dan kendala yang dihadapi dalam pembelajaran bilingual ditampilkan dalam tabel berikut ini:

Tabel 2. Pertanyaan Esai

\begin{tabular}{|c|l|}
\hline No & \multicolumn{1}{|c|}{ Kendala } \\
\hline 1 & $\begin{array}{l}\text { Belum sepenuhnya memahami kosakata } \\
\text { yang ringan }\end{array}$ \\
\hline 2 & $\begin{array}{l}\text { Sebagian taruna tdk mengerti penggunaan } \\
\text { Bhs. Inggris }\end{array}$ \\
\hline 3 & Perlu pengayaan kosakata \\
\hline 4 & Kurang latihan/ praktik \\
\hline 5 & Perlu terjemahan, diselingi Bhs. Inggris \\
\hline & $\begin{array}{l}\text { Dosen jarang masuk, kurang mengikuti } \\
\text { perkembangan teknologi }\end{array}$ \\
\hline 7 & $\begin{array}{l}\text { Dosen belum menguasai materi dengan } \\
\text { baik }\end{array}$ \\
\hline
\end{tabular}

Untuk pertanyaan siapa dosen atau matakuliah apa yang menggunakan penyampaian materi secara bilingual ditampilkan dalam tabel berikut ini:

Tabel 3. Tabel Mata Kuliah

\begin{tabular}{|c|l|}
\hline No & $\begin{array}{c}\text { Mata Kuliah yang Disampaikan dengan } \\
\text { Bilingual }\end{array}$ \\
\hline 1 & Stabilitas Kapal (Capt Valentinus) \\
\hline 2 & Fisika (Jony Purnomo) \\
\hline 3 & Pengaturan/ Penanganan Muatan \\
\hline 4 & Olah Gerak Kapal \\
\hline 5 & Hukum Maritim \\
\hline 6 & Kontrol, Trim \\
\hline 7 & Matematika \\
\hline 8 & Pelayaran Datar \\
\hline 9 & Kimia \\
\hline 10 & Kepemimpinan Etos Kerja \\
\hline
\end{tabular}

Data tersebut di bagi dalam dua klaster, untuk klaster pertama:

1 Pengajar sebaiknya menggunakan metoda bilingual.

2 Pengajar telah menggunakan bilingual.

3 Pengajar menggunakan bilingual dengan baik dan jelas.

4 Pengajar telah menggunakan bahan presentasi berbahasa Inggris.

\section{ASPEK PENGAJAR}

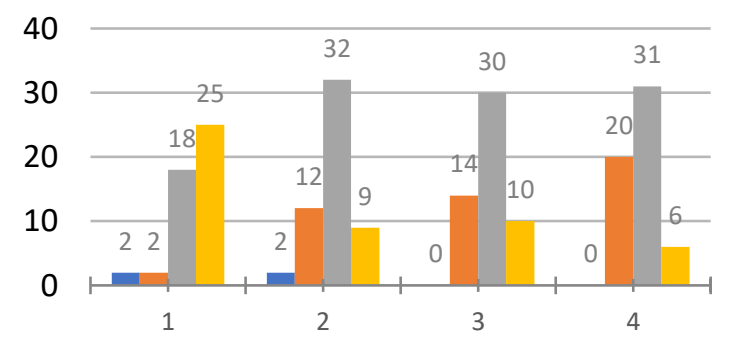

Grafik 1. Aspek Pengajar

Selama 1 (satu) bulan, pengajar yang kami wawancarai menyampaikan tanggapan baik yang positif dan negatif terhadap program ini. Wawancara kami lakukan secara random pada para dosen yang khususnya mengajar di kelas Nautika semester akhir dan tarunanya.

Dalam salah satu wawancara, beberapa orang dosen menyampaikan kesulitannya 
dalam program bilingual adalah kurangnya antusiasme taruna di kelas. Menurut mereka, pengajaran dengan menggunakan Bahasa Indonesia saja sudah sulit bagi taruna untuk memahami kuliah, apalagi bila menggunakan bahasa asing. Mereka tidak menafikan bahwa taruna-taruna ada kalanya bersikap pasif bilamana di kelas, hanya mendengarkan penjelasan dosen dan mengerjakan tugas yang dibebankan pada mereka saja. Mereka tak ingin terlibat aktif dan berpikir kritis sebagaimana yang diharapkan oleh dosen.

Beberapa dosen diwawancarai untuk memperoleh wawasan tentang sikap, kepercayaan dan persepsi mereka. Dan yang menarik adalah pernyataan beberapa dosen yang memandang bahwa program bilingual ini dengan positif, bahwa penguasaan konten perkuliahan dan komunikasi dalam bahasa pengantar bilingual memang dibutuhkan taruna untuk mempersiapkan mereka menghadapi persaingan global di saat ini dan masa yang akan datang. Metode pengajaran memang salah satu yang memegang peran penting dalam penyampaian pengajaran bilingual ini, yaitu agar dosen lebih aktif berkomunikasi dua arah dengan taruna, memberikan pilihan kata yang tak terlalu sulit dipahami oleh taruna serta bersabar/perlahanlahan dalam memberikan penjelasan pada taruna sehingga mereka tak segan bilamana akan berkomunikasi dengan menggunakan bahasa asing.

Taruna yang telah berpartisipasi dalam program bilingual diminta untuk merespon secara tertulis pertanyaan reflektif yang berfokus pada persepsi mereka manfaat atau keuntungan menjadi bilingual di masa depan, keberhasilan dan tantangan yang telah berpartisipasi dalam program bilingual, apa yang mereka sukai dan tidak disukai tentang berada dalam program bilingual, peran dan dirasakan kegunaan dan efektivitas dosen, dan manfaat masa depan partisipasi mereka dalam program bilingual. Beberapa taruna yang kami wawancarai menyampaikan bahwa mereka seringkali mengalami kebosanan di kelas dan kurangnya variasi pengajaran dari dosen sehingga dirasa kurang menarik minat mereka untuk partisipatif di kelas. Tak banyak dosen yang melibatkan taruna di kelas secara aktif dan komunikatif di kelas. Mereka terkadang segan bertanya dan hanya menjawab atau aktif hanya bila ditanya, disapa atau diperhatikan. Dari sini kita bisa menyatakan bahwa dosen sebetulnya bisa melakukan program pengajaran bilingual untuk taruna bilamana mereka diberikan motivasi terus menerus akan pentingnya profesionalisme dan bilingualisme dalam masa mendatang.

Topik survei gaya Likert mencakup item yang mengukur keyakinan, sikap, dan persepsi peserta dan peran dosen, tantangan yang sedang berlangsung dan rintangan, dan tujuan masa depan. Survei termasuk item yang berkaitan dengan praktek mengajar dan penilaian, penggunaan bahasa lisan dan tertulis, pengembangan keterampilan bahasa, dirasakan keberhasilan dan keuntungan dalam bahasa dan konten, dirasakan tantangan atau kesulitan, peran dan efektivitas dosen, dan kebutuhan untuk pengembangan profesional. Dosen sebagian besar antusias tentang peran mereka dalam program bilingual. Dosen pun melihat bahwa pengajaran dengan metode bilingual ini bermanfaat bagi masa depan di dunia pelayaran dan menjadi salah satu cara untuk lebih mempersiapkan taruna agar mampu berkarir di dunia global.

\section{Sementara untuk Klaster Kedua}

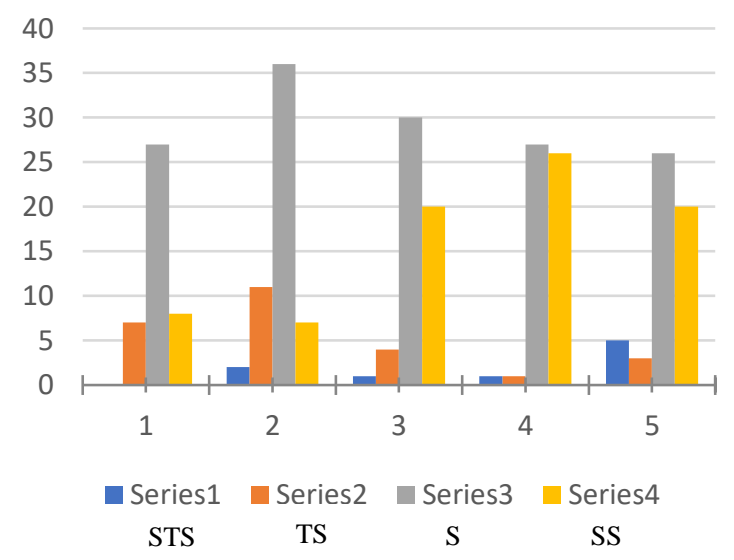


Grafik 2. Aspek Taruna

Masalah yang masih cukup menonjol adalah ketersediaan bahan ajar berbahasa Inggris/ yang mendukung penerapan pengajaran bilingual. Sebagian taruna belum dapat secara optimal memahami materi kuliah yang diberikan dalam bahasa Inggris. Agar dapat berpartisipasi secara efektif di sekolah, taruna harus mencapai tingkat kemahiran berbahasa Inggris yang signifikan. Perlu adanya tingkat minimal kompetensi linguistik dimana seorang siswa harus dapat berfungsi secara efektif dalam mengerjakan tugas-tugas akademik yang menuntut kognitif. Sebaliknya, disarankan untuk membangun pendekatan yang secara bersamaan mengajarkan konten bahasa dan mata kuliah profesi (Cummins, 1981).

Secara umum taruna senang menggunakan bahasa Inggris, termotivasi dalam menggunakan bahasa Inggris dan percaya bahwa pengajaran bilingual telah meningkatkan kemampuan berbahasa Inggris. Taruna menunjukkan bahwa belajar bahasa lain dan menjadi bilingual adalah penting bagi mereka sekarang dan untuk masa depan mereka. Mereka menyadari manfaat dari bilingualisme dan merasakan rasa bangga dan nyaman ketika berbicara bahasa Inggris, dan mereka tidak takut untuk membuat kesalahan. Sebagian besar melihat diri mereka sebagai orang dewasa yang menguasai bahasa asing untuk masa depan, yakin bahwa nantinya mereka akan lebih baik karena partisipasi mereka dalam program bilingual. Mereka menganggap bilingualisme sebagai kunci untuk penerimaan di masyarakat dunia maritim, karir masa depan, pekerjaan dan peluang yang lebih baik, peningkatan persaingan dan kesiapan, dan keuntungan yang lebih besar dan pilihan masa depan. Bahasa Inggris dipandang sebagai bahasa global yang penting dan kemampuan untuk berkomunikasi dengan orang lain akan mengakibatkan peningkatan kemampuan dan pemahaman dalam bahasa Inggris, yang memberikan kemudahan perjalanan antar budaya dan kemampuan komunikatif. Seharusnya bila program bilingual ini bisa dilakukan dengan lebih serius lagi dan melibatkan seluruh civitas akademika STIP, maka belajar kosakata itu bisa dimudahkan, dan sebagai hasilnya, kosakata mereka semakin luas dan kaya, terutama dalam ilmu pelayaran, teknologi, dan kemampuan komunikatif. Namun sayangnya program ini masih seperti setengah hati dilaksanakan sehingga taruna dan dosen kurang antusias dalam memaknainya, walau mereka mengetahui manfaatnya.

Secara pribadi, beberapa taruna menyatakan tingkat kepercayaan diri yang lebih tinggi, tingkat kenyamanan, perasaan prestasi dan rasa kebanggaan ketika mampu berkomunikasi dan belajar dalam bahasa asing. Mereka umumnya menyukai dosen mereka, berpikir bahwa dosen mereka sangat kompeten, dan menemukan kelas lebih challenging. Kata sifat positif yang digunakan taruna untuk menggambarkan keterlibatan mereka dalam program bilingual berkisar dari "gembira, puas, tertarik, nyaman, dan percaya diri".

\section{PENUTUP}

Dalam penerapan kelas bilingual tentunya terdapat faktor-faktor pendukung dan juga faktor-faktor penghambat untuk menuju pembelajaran efektif yaitu : faktor pendukung antara lain : a) pimpinan dengan visi yang jelas, b) pengajar dengan rasa percaya diri dan kemampuan berbahasa Inggris yang baik, c) taruna yang mempunyai bekal cukup dalam penguasaan bahasa, dan d) Faktor pendukung: kampus, orang tua, dan sarana prasarana; sedangkan untuk faktor penghambat yaitu masalah dan kendala yang timbul tentang taruna yang kurang menguasai bahasa Inggris dan rata-rata kemampuan bahasa Inggris taruna yang masih kurang atau pasif, kemampuan pengajar dalam kelas masih perlu diasah. Kompetensi pengajar belum mampu 
menggunakan bahasa Inggris pula menjadi kendala dalam mencapai tujuan yang diharapkan.

Sebagian mata kuliah sudah diajarkan dalam Bahasa Inggris atau secara bilingual. Sebagian pengajar memiliki kemampuan mengajar dengan cara bilingual dan mampu mengembangkan metode penyampaian yang baik sehingga target pemahaman substansi materi pembelajaran dapat terpenuhi. Taruna perlu dibiasakan kemampuan speaking dan listening-nya. Sebagian besar dosen yang mengajar di semester tersebut belum menggunakan bahasa Inggris sebagai alat komunikasi di kelas. Sebagian dari mereka yang melaksanakan program bilingual mengalami kesulitan dalam penggunaan kosakata yang sesuai dengan mata kuliah yang diampu masing-masing, seperti bidang olah gerak atau matematika. Di samping itu, ada beberapa permasalahan yang muncul di lapangan misalnya, belum adanya modul pembelajaran yang disesuaikan dengan mata kuliah masing-masing dalam bahasa Inggris/bilingual, sebagian besar belum melakukan evaluasi belajar dalam bahasa Inggris, dosen menilai kurangnya dukungan secara serius dari seluruh civitas akademika.

\section{DAFTAR PUSTAKA}

[1] Arnyana, I. 2006. "Pengembangan Model Pembelajaran Bilingual Preview-Review Dipandu Strategi STAD dalam Pembelajaran Sains di SMA". Jurnal Pendidikan dan Pengajaran UNDIKSHA, 2(1), 87-96.

[2] Chotijah, I. 2000. "Kemampuan berbahasa Inggris anak dengan pembelajaran bilingual". Jurnal Pendidikan Penabur , 9 (1), 103-117.

[3] Cummins, J. (2000). Language, power, and pedagogy: Bilingual children in the crossfire (Vol. 23). Clevedon: Multilingual Matters.
[4] Gunarsa, Singgih D. 2006. "Dari Anak Sampai Usia Lanjut : Bunga Rampai Psikologi Perkembangan". Jakarta, Gunung Mulia.

[5] Hugo Baetens Beardsmore (ed.). 1993. "European models of bilingual education". (Multilingual matters, 92.) Clevedon (England) \& Philadelphia: Multilingual Matters.

[6] Blanco, G. 1977. " The Education Prespective. Bilingual Education : Current Perspectives, Education", 1-68. Arlington, Va. : Center for Applied Linguistics. 